Науковий вісник Чернівецького університету імені Юрія Федьковича: Історія. - № 2. - 2020.- С. 45-51

History Journal of Yuriy Fedkovych Chernivtsi National University. - № 2. -2020 . - pp. 45-51

DOI https: /doi.org/10.31861/hj2020.52.45-51

hj.chnu.edu.ua

УДК 94 (477)+322 «18/19»

(С) Олексій Кошель* (Чернівці)

\title{
РОЛЬ ПРАВОСЛАВНОГО ДУХОВЕНСТВА ПРАВОБЕРЕЖНОЇ УКРАЇНИ У ЗАХИСТІ ПРАВ І СВОБОД СЕЛЯНСТВА (ДРУГА ПОЛОВИНА XIX - ПОЧАТОК XX СТ.)
}

У середині - другій половині ХІХ ст. в українських спархіях РПЦ сформувалася частина опозииійного до духовної та імперської влади духовенства, яка відстоювала національні иерковні традиції, українську мову та культуру, соџіальні права пастви, насамперед селянства. Їхня роль у захисті прав і свобод селянського населення проявлялася під час конфліктів із поміщиками, орендаторами, чиновниками, у написанні колективних скарг до державних і духовних інстанцій, виступів у судах, підтримкою акиій непокори селян, розвитку освіти, кооперативного та революиійного руху тощзо. Укази Синоду свідчать, щуо за свою активну участь у виступах селянства та захисті їхніх прав представники духовенства зазнавали переслідувань з боку духовної влади. Діяльність представників православного духовенства сприяла украӥнізації иеркви, освіти, культурного життя сільського населення, активізувала громадське життя селян та стала основою розвитку украӥнського національного та духовного відродження.

Oleksii Koshel (Chernivtsi)

\section{THE ROLE OF THE ORTHODOX CLERGY OF THE RIGHT BANK UKRAINE IN THE PROTECTION OF THE RIGHTS AND FREEDOMS OF THE PEASANTRY (SECOND HALF OF THE 19th - THE BEGINNING OF THE 20th CENTURY)}

Abstract. In the middle of the 19th century among the Orthodox clergy of the Ukrainian dioceses of the ROC, there was a clear division between the Orthodox, who served the interests of the autocracy and opposed the reforms of the church and its ukrainization, and the liberal clergy. Liberal, patriotic clergy were openly opposed to the religious and imperial authorities, defended the Ukrainian language and culture, social rights of the congregation, especially the peasantry.

The representatives of the clergy were persecuted by the church authority for their active participation in the defence and protests of the peasantry. This is evidenced by the decrees of the Synod and its secret correspondence with the Metropolitan of Kyiv in 1848-1850 on the strengthening of supervision over the clergy in connection with the participation of some priests in peasant riots.

The patriotic part of Ukrainian clergy also actively defended the interests of the peasantry during conflicts with tenants, landlords, officials, helped to write collective complaints to state and clergy officials, defended them in court, and developed rural education. Such activities of the clergy contributed to the reform of the church, the development of the Ukrainian national revival and the struggle for the autocephaly of the Ukrainian church.

In the late 19th - early 20th century the representatives of the Orthodox clergy also played a significant role in the development of rural consumer, credit and industrial cooperation. The cooperative movement not only improved the material and cultural standard of living of the Ukrainian peasantry, but

* к. і. н., докторант Чернівецького національного університету імені Юрія Федьковича.

$\mathrm{PhD}$ in History, Doctoral Student Yuriy Fedkovych Chernivtsi National University.

orcid.org/0000-0002-0347-328X

E-mail: koshel@cvu.kiev.ua 
also significantly intensified the social life of the peasants and contributed to the development of their selforganization.

Keywords: Orthodox clergy, peasantry, Right Bank Ukraine, ROC, national revival, cooperative movement.

Проблема взаємин духовенства українських єпархій Російської православної церкви з українським селянством у другій половині XIX - на початку XX ст. в дослідницькому та історіографічному плані є досить складною. Радянська історіографії 20-80-х рр. XX ст. грунтувалася на класових та атеїстичних позиціях, доводила реакційну, антинародну сутність православного духовенства та акцентувала увагу на його конфліктах із віруючими. Названий підхід характерний для праць таких істориків, як Б. Титлинов ${ }^{1}$, Д. Пойда ${ }^{2}$, М. Лещенко ${ }^{3}$, О. Коломієць ${ }^{4}$ та ін. Їхні дослідження визнані, підтримуються сучасною вітчизняною історіографією та містять значний фактологічний матеріал.

Втім, у зазначених роботах не розглядався той факт, що саме в лавах РПЦ у досліджуваний період формувалося українське православне духовенство патріотичного напряму, яке виступило за переклад Св. Письма українською мовою, збереження національних традицій та історико-культурної спадщини, а також захищало права і свободи селянства, підтримувало його у соціальних конфліктах з офіційною владою, поміщиками та консервативним духовенством. У незалежній Україні ці теми стали пріоритетними для дослідників, які вивчають роль духовенства в українському національно-культурному і духовному відродженні: А. Зінченка 5 , О. Ігнатуші ${ }^{6}$, В. Меши ${ }^{7}, \Gamma$. Надтоки Д. Степовика ${ }^{9}$ Ю. Хитровської ${ }^{10}$ та ін.

Мета цієї статті - дослідити роль патріотично налаштованого духовенства Правобережної України у захисті прав і свобод селянства у другій половині XIX - на початку XX ст. Ї̈̈ досягнення передбачає вирішення таких завдань:

- проаналізувати роль представників духовенства у захисті селян після проведення інвентарної реформи $1847-1848$ рр.;

- охарактеризувати виступи духовенства із критикою політики імперської та духовної влади, спрямованої проти селянства у пореформений період 60-90-х рр. XIX ст.;

- розглянути участь церковнослужителів у революційному русі кінця 60 - 80-х рр. ХІХ ст.;

- проаналізувати роль духовенства у становленні та розвитку споживчої кооперації наприкінці $\mathrm{XIX}$ - на початку XX ст.

У досліджуваний період церковне життя та діяльність парафіяльного духовенства Правобережної України тісно перепліталося з суспільними процесами та громадським життям. Оскільки представники духовенства часто були чи не єдиними освіченими особами у селах, то на них, поза богослужіннями, покладалася низка обов'язків, яких потребувала сільська громада.

Поширеною серед священників була посада духовного депутата - особи, що була присутня при розслідуванні церковної справи цивільними слідчими. Їм доручалося виконувати функції «мирового судді» у спорах селян між собою або із землевласником, у випадках дрібного хуліганства, бійок, сімейних сварок тощо. ${ }^{11}$ Священник, за відсутності лікаря, надавав селянам першу медичну допомогу, мав навики правника, статиста, будівельника. Одним із найважливіших обов'язків духівника було відкриття в селі школи, викладання в навчальних закладах Закону Божого та інших предметів.

Далеко не кожна сільська парафія мала авторитетних священників. У фондах архівів церковних і державних відомств України та Росії зберігаються численні справи і документи про неблаговидну діяльність багатьох сільських священнослужителів другої половини XIX - початку XX ст. Показовим є той факт, що, за підрахунками сучасного дослідника В. Тацієнка, у Київській єпархії впродовж 1800-1917 pр. було притягнуто до слідства і суду, накладено єпитимії за побиття, образи та грубе ставлення до парафіян, хабарництво, розтрати, привласнення церковних грошей і майна, поширення неправдивих чуток 2219 священнослужителів. ${ }^{12}$

Однак у середовищі духовенства українських єпархій РПЦ у середині ХІХ ст. сформувалася значна група патріотично налаштованого духовенства, вихідців переважно із спадкових священницьких родин. Вони часто були в опозиції до світської та духовної влади, виступали проти русифікації церкви, активно відстоювали соціальні права пастви, насамперед селянства.

Яскравим прикладом такої діяльності є постать подільського протоієрея Михайла Орловського (1807-1887). Як історик і краєзнавець він проводив масштабну роботу по збиранню фольклорно- 
етнографічного матеріалу, зокрема у 1861 р. передав П. Кулішу понад 2 тис. подільських прислів'їв та говірок, зібраних ним у Проскурівському повіті, а в 1884 р. - редакції журналу «Киевская старина» ще 1300 прислів”їв. Значну кількість матеріалів він опублікував у подільських «Єпархіальних відомостях», у тому числі «Українські прислів’я і приказки (числом 844), розміщених в алфавітному порядку», «Народні казки, повір'я, перекази і пісні про старовину» та ін. ${ }^{13}$

Водночас Михайло Орловський проводив активну громадську роботу по захисту мирян-односельчан. Напередодні реформи 1861 р. він увійшов до складу повітових і губернських комісій з розгляду аграрних законопроєктів, захищав інтереси селян щодо отримання ними земельних наділів та дотримання їхніх громадянських прав. У 1860-1870-х рр. постійно захищав селян в судах у справах спорів за межі земельних наділів, утиски та образи. В дискусіях із шляхтичами і русофілами відстоював право українського народу на своє існування, завжди розмовляв барвистою українською мовою, насиченою подільськими діалектами. Про М. Орловського у 1887 році подільські «Єпархіальні відомості» писали: «Протоієрей Михайло Орловський належав до числа кращих пастирів Поділля... був найвидатнішим в середовищі бідного сільського духовенства... володів найбільш широкими історичними знаннями, був талановитим письменником на тлі історії краю». ${ }^{14}$

Такий самий слід у середовищі сільських віруючих та волинської інтелігенції залишив протоієрей Аполлон Сендульський (1830-1882), який вів активне громадське і науково-краєзнавче життя, став одним 3 фундаторів історичного волинезнавства. ${ }^{15}$ Він також ревно захищав селян від свавілля поміщиків, заснував церковнопарафіяльну школу та недільні курси грамоти для дорослих. Вшановуючи пам'ять Сендульського, часопис «Киевская старина» у 1882 р. опублікував його повну автобіографію, де у передмові було зазначено: «Отець Аполлоній Сендульський прекрасна людина, освічений священник - пастир, непересічний діяч-адміністратор і найвидатніший місцевий учений-історик». ${ }^{16}$

До числа духовенства, яке проводило активну діяльність по захисту інтересів селянства, варто також віднести Стефана Барановського, Василя Гречулевича, Миколу Машкевича, Петра Лебединцева, Леонтія Гримальського, Марка Грушевського та ін. Саме такі патріотично налаштовані пастори формували основу для українського національного і духовного відродження.

Вже в середині XIX ст. у середовищі православного духовенства українських єпархій РПЦ активно народжувалося і ширилося вільнодумство, відверта опозиційність до духовної та імперської влади, яка проявлялася в участі священників у виступах селян. Про це свідчать укази Синоду та його таємне листування з київським митрополитом у 1848-1850-х рр. про посилення нагляду за духовенством у зв'язку з випадками участі деяких священників у селянських заворушеннях після проведення так званої інвентарної реформи. ${ }^{17}$

У державних архівах зберігаються справи щодо звинувачення священників с. Яснозірки С. Данилевського ${ }^{18}$, с. Макіївки Василя Антонова - Київської губернії ${ }^{19}$, с. Зачернеччя паламаря Львовича - Волинської губернії ${ }^{20}$, священника Владишевського - Подільської єпархії ${ }^{21}$ та інших у написанні ними низки колективних скарг на захист селян, організації селянських заворушень проти місцевих поміщиків та несправедливості у запровадженні нових інвентарних правил. Зазвичай єпархіальна влада накладала єпитимію на таких священників, засилала у віддалені монастирі або навіть позбавляла сану.

Напередодні реформи 1861 р. та під час скасування кріпацтва посилилися соціальні виступи селян. Зокрема, часопис «Киевская старина» у 1882 р. опублікував посмертну розповідь о. Антонія Ковальського, в якій виклав історію масових селянських заворушень, які прокотилися в 1855 р. у Київській губернії, та причетності до них сільських священників. ${ }^{22}$ Показовими $є$ опубліковані спогади в журналі «Русская старина» протоієрея Михайла Ковальського, який був священником парафії в с. Іванківці Ушицького повіту Подільської губернії у $1853-1858$ pp. ${ }^{23}$ Він детально описав становище селян у селах парафії, які належали поміщику К. Собанському. У спогадах докладно описуються злочини поміщика проти селян, втручання у релігійне життя, заборони відкрити у парафії школу для дітей. Священник не лише надсилав скарги до губернської і повітової влади, але й організував страйк селян з вимогою зупинити свавілля поміщика. Селянський страйк було придушено $з$ допомогою поліції, а священника усунено з парафії.

У пореформений період 60-90-х рр. XIX ст. набули поширення проповіді під час богослужінь, у яких гостро викривалася політика імперської та духовної влади, спрямованої проти селянства, їх 
жорстоке гноблення поміщиками, орендаторами, чиновниками. Прикладом може слугувати справа у звинуваченні священника м. Кагарлик Київської губернії О. Радецького у виголошенні в церкві проповіді, в якій засуджувалися центральна і місцева влада за гноблення селян (1881р.). ${ }^{24}$ За поданням міністерства внутрішніх справ до відповідальності у 1878 р. за такі проповіді було притягнуто священника Київської єпархії Федора Стрижевського ${ }^{25}$ та ін.

Також була помітною роль патріотично налаштованого сільського духовенства в народницькому русі, соціалістичній пропаганді 70-80-х pp. XIX ст. 3-поміж українського селянства. Про це свідчать справи канцелярії київського генерал-губернатора: «Донесення про таємну діяльність у Південно-Західному краї духовних осіб, які вважають себе членами партії «Народна воля» 26 , «Циркуляр департаменту поліції від 3 квітня 1884 року про отримання відомостей про поведінку, образ життя і судимостей неблагонадійних осіб духовного звання» ${ }^{27}$ та ін. Серед таких справ привертає увагу жандармське розслідування «Про злочинну пропаганду священиків села Ромейковки Звенигородського повіту Київської губернії Дмитра Мельниковського і села Кирилівки Олексія Кошика» $(1878 \text { р. })^{28}$, які проводили революційну агітацію серед селян, читали і поширювали прокламації про передачу селянам землі, закликали до непокори поміщикам та чиновникам; справа про перевірку священника с. Бубнів Володимирського повіту Волинської губернії Мальчевського щодо приналежності до таємного товариства (1883 р.) $)^{29}$ тощо.

Характеризуючи стосунки духовенства та українського селянства, варто звернути увагу на такий аспект, як роль священників у становленні в регіонах України наприкінці XIX - на початку XX ст. сільської споживчої, кредитної і виробничої кооперації як одного з ефективних засобів підвищення матеріального добробуту, самоорганізації та активізації громадського життя селян. Початки створення таких кооперативних товариств у Правобережній Україні припали на 1860-ті pp., які були першими для набуття цього досвіду. Масовий кооперативний рух започаткувався з 1897 р., а його утвердження і розквіт припали на 1910-1914 pp..$^{30}$ Ідея кооперації стала настільки популярною, що ііі підтримувала переважна більшість населення краю, а також чимало священнослужителів. Так, у 1912 р. в селах та містечках Вінницького, Кам’янецького, Проскурівського повітів Подільської губернії було зареєстровано 84 новоутворені споживчі товариства, у тому числі в 27 із них засновниками виступили священники, диякони, вчителі церковнопарафіяльних шкіл. ${ }^{31}$

Особливо помітною в середовищі священників того часу була постать настоятеля с. Гуків Кам'янецького повіту Олександра Маричева ${ }^{32}$, який виступив ініціатором створення споживчих і кредитних товариств у багатьох селах Подільської губернії, виконував обов'язки інструктора кооперативного руху в Кам'янецькому, Летичівському, Проскурівському і Ушицькому повітах. Чимало зробили для поширення подільської кооперації священники Михайло Ковальчук та Григорій Пілін. У численних поїздках до сіл вони агітували, розповсюджували серед місцевих жителів кооперативні газети, брошури, виступали з лекціями, допомагали створювати кооперативні товариства.

Участь у кооперативному русі не приносила представникам духовенства жодних матеріальних вигод. Навпаки, часто їхня діяльність перешкоджалася духовною владою, чиновниками, торговцями, котрі не підтримували кооперативний рух. Однак масова подвижницька діяльність духовенства 3 підтримки кооперативного руху позитивно вплинула на його розвиток, покращення матеріального і культурного рівня сільського населення України, сприяла розвитку громадської активності селян.

На жаль, питання участі церковнослужителів у революційному русі кінця 60 - 80-х pp. XIX ст. обійдені серйозними дослідженнями в історіографії. Досі часто превалює позиція про реакційне ставлення духовенства РПЦ до реформаторських і революційних процесів того часу та до потреб українського селянства. Однак у середовищі кліру РПЦ, як свідчать вищезазначені приклади, активно діяло ліберальне, патріотичне духовенство, яке у різних формах обстоювало інтереси парафіян, насамперед селянства (у конфліктах з поміщиками, орендаторами, чиновниками, у написанні колективних скарг у різні державні й духовні інстанції, виступах у судах, підтримкою селянських протестних акцій, розвитку освіти у селах, кооперативного та революційного руху тощо). Своєю активною діяльністю вони також домагалися реформи церкви, іiї українізації, робили церкву об'єктом українського національного і духовного відродження. 
1 Б. Титлинов. Православие на службе самодержавия [Orthodoxy in the service of autocracy], Ленинград, Госиздат, 1924.

2 Д. Пойда. 3 історії боротьби украӥнського селянства проти духовенства в дореволюиійний час [From the history of the struggle of the Ukrainian peasantry against the clergy in pre-revolutionary times]. Дніпропетровськ, Дніпропетр. обл. вид-во, 1958.

3 М. Лещенко. Класова борьба в украӥнському селі в епоху домонополістичного капіталізму (60-90-ті роки XIX cm.) [Class struggle in the Ukrainian countryside in the era of pre-monopoly capitalism (60-90s of the XIX century)]. Київ, Наукова думка, 1980.

4 О. Коломієць. Антиклерикальні виступи селян Правобережної Украӥни в 1900-1914 рp. [Anti-clerical riots of the peasants of the Right Bank of Ukraine in 1900-1914] in Укр. істор. журн, 1973, № 11, с. 108-115.

5 А. Зінченко. Народна традиція та духівництвво на Поділлі наприкіниі ХІХ - на початку XX cm. [Folk tradition and clergy in Podillia in the late XIX - early XX century] in Етнографія Поділля: тези доповідей наукоа вої конференції, Вінниця, Б.в., 1992, с. 15-21.

6 О. Ігнатуша. Інституиійний розкол православної иеркви в Україні: тенеза і характер (XIX сm. - 30-ті pp. $X X \mathrm{~cm}$.) [System split of the Orthodox Church in Ukraine: genesis and character (XIX century - the 30s of the XX century)]. Запоріжжя, Поліграф, 2004, 440 c.

7 В.Меша. Православна церква і селянство України останньої чверті XIX cm. [The Orthodox Church and the peasantry of Ukraine in the last quarter of the XIX century] in Український селянин: збірник наукових праць. Черкаси, 2008, № 11. С. 173-176.

8 Г. Надтока. Православна и̧ерква і процес украӥнського національного відродження 1900-1917 років. [The Orthodox Church and the process of Ukrainian national revival in 1900-1917] Київ, Вид-во Київ. нац. ун-ту ім. Т.Г. Шевченка, 1996, 110 с.

9 Д. Степовик. Церква в кайданах (Боротьба українських християн за свою самобутність у XIX ст. [Church in chains (The struggle of Ukrainian Christians for their identity in the XIX century] Київ, 1996,112 c.

10 Ю. Хитровська. Правобережне православне духовенство та украӥнський національний рух у XIX-на початку XX cm. [Right-bank Orthodox clergy and the Ukrainian national movement in the XIX - early XX centuries] in Інтелігенція і влада: збірник наукових праць. Одеса: Астропринт, 2008, Вип. 13, С. 30-45.

11 Сельский пастырь в роли мирового судьи [A country parson as the justice of the peace] in Руководство для сельских пастырей. Москва, 1886, № 50.

12 В. Тацієнко. Повсякденне життя православного парафіяльного духовенства Київської єпархї̈ в кінці XVIII - на початку XX ст.: дис. канд. істор. наук. [Everyday life of the Orthodox parish clergy of the Kyiv eparchy in the late eighteenth - twentieth century] Умань, 2016. $272 \mathrm{c}$.

13 К. Добровольский. Памяти протоиерея Михаила Орловского [In memory of the archpriest Mikhail Orlovsky] in Подольские епархиальные ведомости, 1887, № 12, с. 276-278.

14 К. Добровольский. Памяти протоиерея Михаила Орловского [In memory of the archpriest Mikhail Orlovsky], c. 277.

15 Л.Баженов. Аполлоній Сендульський - діяч украӥнського національного відродження, видатний краєзнавецьь Волині [Apollonius Sendulsky - a figure of the Ukrainian national revival, an outstanding local Volyn historian] in Духовне відродження культури України. Матеріали науково-практичної конференції. Рівне, 1994, c. 76-78.

16 А.Сендульский. Автобиография [Autobiography] in Киевская старина. 1896, № 1, с. 58-59.

17 Центральний державний історичний архів, м. Києві (далі - ЦДІАУК), ф.182, оп. 1, спр. 83. Секретна переписка Синода з Київським митрополитом про посилення нагляду за духовенством в зв'язку з випадками участі деяких священиків у селянських заворушеннях. 1848 p, 9 арк.

18 ЦДІАУК, ф. 127, оп. 2, спр. 810. Справа про священика села Ясногородки Київського повіту Стефана Данилевського, зісланого в монашество за підбурювання селян-кріпаків проти місиевого помішика. 1845-47 рр., 28 арк.

19 ЦДІАУК, ф.182, оп. 1, спр. 64. Справа по звинуваченню парафіяльного священика с. Макї̈вки, Київської губ. Антонова Василя у написанні низки колективних скарг на захист селян, в організаџї селянського заворушення, звільнення з-під варти селян тощзо. 1845 р., 7 арк.

20 ЦДІАУК, ф. 442, оп. 451, спр. 45. Справа про підбурювання селян в маєтку графа Міончинського с. Зачернеччя Ковельського пов. Волин. губ. пономарем Львовичем до непокори влавласнику їх. 1848 р., 24 арк.

21 ЦДІАУК, ф. 797, оп. 17, спр. 40189. По звинуваченню священика Подільської єпархії Владишевського в підбуренні до заворушень селян проти поміщиків Галищького і Поповського. 1847-1848 рр., арк. 1-8. 
22 Посмертный рассказ о. Антония Ковальского (к истории крестьянских волнений в Киевской губернии 1855 года) [The posthumous story of Anthony Kowalski (to the history of the peasants riots in the Kiev province in 1855)] in Киевская старина, 1882, Т. 1, с. 386-396.

23 М.Ковальский., прот. Из подольской стариньл [From Podolsk antiquity] in Русская старина, СанктПетербург, 1911, с. 229-552.

24 ЦДІАУК, ф. 442, оп. 831, спр.143. Донесення київському губернатору про виголошення священиком м. Кагарлик Київького повіту Радеияьким О. проповіді, в якій засуджується иеентральна і місиева влада за пригноблення селян. 1881 р., арк. 1-2.

25 ЦДІАУК, ф. 797, оп. 45, відділення 3, спр. 175. Циркуляр Міністерства внутрішніх справ про неблагодійну поведінку в иеекві священика Київської єпархї Федора Стрижевського. 1878 р. 12 арк.

26 ЦДІАУК, ф. 274, оп.1, спр. 242. Донесення про таємну діяльність у Південно-Західному краї осіб, які вважають себе членами партї «Народна воля». 1882 р., 35 арк.

27 ЦДІАУК, ф.1335, оп. 1, спр. 20. Циркуляр департаменту поліції від 3 квітня 1884 р. про отримання відомостей про поводження, образ життя і судимості неблагонадійних осіб духовного звання в місиевого єпархіального начальства. 222 арк.

28 ЦДІАУК, ф. 797, оп. 48, відд. 3, спр. 181. По відношенню Головного начальника 3 відділення Особистої Його Величності Канцелярї про притягнутих до відповідальності у справі злочинної пропаганди священиків Київської губ. Звенигородського повіту села Ромейковки Дмитра Мельниківського і с. Кирилівки Олексія Кошика. 1878 р., арк. 1-8.

29 ЦДІАУК, ф. 442, оп. 833, спр. 13. Переписка з Волин. губ. про перевірку анонімної заяви про належність до таємного товариства свящеенкка с.Бубнів Володимирського повіту Волин. губ. Мальчевского. 1883 р., арк. 1-3.

30 Подолян В., Рекрут В. Йоахим Волошиновський у становленні украйнського кооперативного руху: монографія [Joachim Voloshinovsky in the formation of Ukrainian cooperative movement]. Вінниця, $2005.400 \mathrm{c}$.

31 Отзывы епархиальных архиереев по вопросу о иерковной реформе: сборник документов [Reviews of diocesan bishops on the issue of church reform: collection of documents]. Москва, 2004, с.34.

32 Ю.Блажевич. Нариси історії православ'я Поділля-Хмельниччини [Essays on the history of Orthodoxy in Podillya-Khmelnytsky region] Хмельницький, ФОП Сікорська С.В., 2017, с. 131.

\section{References}

1. L. Bazhenov. Apollonij Sendul's 'kyj - diiach ukrains 'koho natsional'noho vidrodzhennia, vydatnyj kraieznavets' Volyni [Apollonius Sendulsky - a figure of the Ukrainian national revival, an outstanding local Volyn historian] in Dukhovne vidrodzhennia kul'tury Ukrainy. Materialy naukovo-praktychnoi konferentsii, Rivne, 1994, s. 76-78.

2. Yu. Blazhevych. Narysy istorii pravoslav'ia Podillia-Khmel'nychchyny [Essays on the history of Orthodoxy in Podillya-Khmelnytsky region], Khmel'nyts'kyj, FOP Sikors'ka S.V., 2017, 337 s.

3. Dobrovol'skyj K. Pamiaty protoyereia Mykhayla Orlovskoho [In memory of the archpriest Mikhail Orlovsky] in Podol'skye eparkhyal'nye vedomosty, 1887, № 12, s. 276-278.

4. A. Zinchenko. Narodna tradytsiia ta dukhivnytstvo na Podilli naprykintsi XIX - na pochatku XX st. [Folk tradition and clergy in Podillia in the late XIX - early XX century] in Etnohrafiia Podillia: tezy dopovidej naukovoi konferentsii, Vinnytsia, B.v., 1992, s. 15-21.

5. O. Ihnatusha. Instytutsijnyj rozkol pravoslavnoi tserkvy v Ukraini: geneza i kharakter (st. - 30-ti rr. XX st.) [System split of the Orthodox Church in Ukraine: genesis and character (XIX century - the 30s of the XX century)], Zaporizhzhia, Polihraf, 2004. $440 \mathrm{~s}$.

6. M. Koval'skyj, prot. Yz podol'skoj staryny [From Podolsk antiquity] in Russkaia staryna, Sankt-Peterburh, 1911, s. 229-552. [in Russian]

7. O. Kolomiiets' O.M. Antyklerykal'ni vystupy selian Pravoberezhnoi Ukrainy v 1900-1914 rr. [Anti-clerical riots of the peasants of the Right Bank of Ukraine in 1900-1914] in Ukr. istor. zhurn, 1973, № 11, s. 108-115.

8. M. Leschenko. Klasova bor'ba v ukrains'komu seli v epokhu domonopolistychnoho kapitalizmu (60-90-ti roky XIX st.) [Class struggle in the Ukrainian countryside in the era of pre-monopoly capitalism (60-90s of the XIX century)], Kyiv, Naukova dumka, 1980, 260 s.

9. V. Mesha. Pravoslavna tserkva i selianstvo Ukrainy ostann'oi chverti XIX st. [The Orthodox Church and the peasantry of Ukraine in the last quarter of the XIX century] in Ukrains'kyj selianyn: zbirnyk naukovykh prats', Cherkasy, 2008, № 11, s. 173-176.

10. H. Nadtoka. Pravoslavna tserkva i protses ukrains'koho natsional'noho vidrodzhennia 1900-1917 rokiv [The Orthodox Church and the process of Ukrainian national revival in 1900-1917], Kyiv, Vyd-vo Kyiv. nats. un-tu im. T.H. Shevchenka, 1996, 110 s. 
11. Otzyvy eparkhyal'nykh arkhyereev po voprosu o tserkovnoj reforme: sbornyk dokumentov [Reviews of diocesan bishops on the issue of church reform: collection of documents], Moskva, 2004, 220 s. [in Russian]

12. D. Pojda. Z istorii borot'by ukrains 'koho selianstva proty dukhovenstva v dorevoliutsijnyj chas [From the history of the struggle of the Ukrainian peasantry against the clergy in pre-revolutionary times]. Dnipropetrovs'k, Dnipropetr. obl. vyd-vo, 1958, $82 \mathrm{s.}$

13. V. Podolian, V. Rekrut. Joakhym Voloshynovs 'kyj u stanovlenni ukrains 'koho kooperatyvnoho rukhu: monohrafiia [Joachim Voloshinovsky in the formation of Ukrainian cooperative movement: monograph]. Vinnytsia, 2005, $400 \mathrm{~s}$.

14. Posmertnyj rasskaz o. Antonyia Koval'skoho (k ystoryy krest'ianskykh volnenyj v Kyevskoj hubernyy 1855 hoda) [The posthumous story of Anthony Kowalski (to the history of the peasants riots in the Kiev province in 1855)] in Kyevskaia staryna, 1882, T. 1, fevral', S. 386-396.

15. Sel'skyj pastyr'v roly myrovoho sud'y [A country parson as the justice of the peace] in Rukovodstvo dlia sel’skykh pastyrej. Moskva, 1886, № 50. [in Russian]

16. A. Sendul'skyj. Avtobyohrafyia [Autobiography] in Kyevskaia staryna. 1896. № 1. s. 58-59.

17. Stepovyk D. Tserkva v kajdanakh (Borot'ba ukrains'kykh khrystyian za svoiu samobutnist'u XIX st. [Church in chains (The struggle of Ukrainian Christians for their identity in the XIX century], Kyiv, 1996, $112 \mathrm{s.}$

18. V. Tatsiienko. Povsiakdenne zhyttia pravoslavnoho parafial'noho dukhovenstva Kyivs'koi ieparkhii v kintsi XVIII- na pochatku XIX st.: dys. kand. istor. nauk [Everyday life of the Orthodox parish clergy of the Kyiv eparchy in the late eighteenth - early twentieth century], Uman', 2016. $272 \mathrm{~s}$.

19. B. Tytlynov. Pravoslavye na sluzhbe samoderzhavyia [Orthodoxy in the service of autocracy]. Lenynhrad, Hosyzdat, 1924. 207 s. [in Russian]

20. Yu. Khytrovs'ka. Pravoberezhne pravoslavne dukhovenstvo ta ukrains'kyj natsional'nyj rukh u XIX - na pochatku XX st. [Right-bank Orthodox clergy and the Ukrainian national movement in the XIX - early XX centuries], in Intelihentsiia i vlada: zbirnyk naukovykh prats', Odesa, Astroprynt, 2008, Vyp. 13, s. 30-45.

21. Tsentral'nyj derzhavnyj istorychnyj arkhiv, m. Kyievi (dali-TsDIAUK), f.182, op. 1, spr. 83. Sekretna perepyska Synoda z Kyivs'kym mytropolytom pro posylennia nahliadu za dukhovenstvom v zv'iazku z vypadkamy uchasti deiakykh sviaschenykiv u selians'kykh zavorushenniakh. 1848 r., 9 ark.

22. TsDIAUK, f. 127, op. 2, spr. 810. Sprava pro sviaschenyka sela Yasnohorodky Kyivs'koho povitu Stefana Danylevs'koho, zislanoho v monashestvo za pidburiuvannia selian-kripakiv proty mistsevoho pomischyka. 1845-1847 rr., 28 ark.

23. TsDIAUK, f.182, op. 1, spr. 64. Sprava po zvynuvachenniu parafiial'noho sviaschenyka s. Makiivky, Kyivs'koi hub. Antonova Vasylia u napysanni nyzky kolektyvnykh skarh na zakhyst selian, v orhanizatsii selians'koho zavorushennia, zvil'nennia z-pid varty selian toscho. 1845 r., 7 ark.

24. TsDIAUK, f. 442, op. 451, spr. 45. Sprava pro pidburiuvannia selian v maietku hrafa Mionchyns'koho s. Zachernechchia Kovel's'koho pov. Volyn. hub. ponomarem L'vovychem do nepokory ikh vlavlasnyku. 1848 r., 24 ark.

25. TsDIAUK, f. 797, op. 17, spr.40189. Po zvynuvachenniu sviaschenyka Podil's'koi ieparkhii Vladyshevs'koho v pidburenni do zavorushen' selian proty pomischykiv Halyts'koho i Popovs'koho. 1847-1848 rr., ark. 1-8.

26. TsDIAUK, f. 442, op. 831, spr.143. Donesennia kyivs'komu hubernatoru pro vyholoshennia sviaschenykom m. Kaharlyk Kyivs'koho povitu Radets'kym O. propovidi, v iakij zasudzhuiet'sia tsentral'na i mistseva vlada za pryhnoblennia selian. 1881 r., ark. 1-2.

27. TsDIAUK, f. 797, op. 45, vidd. 3, spr. 175. Tsyrkuliar Ministerstva vnutrishnikh sprav pro neblahodijnu povedinku v tserkvi sviaschenyka Kyivs'koi ieparkhii Fedora Stryzhevs'koho. 1878 r., 12 ark.

28. TsDIAUK, f. 274, op.1, spr. 242. Donesennia pro taiemnu diial'nist' u Pivdenno-Zakhidnomu krai osib, iaki vvazhaiut' sebe chlenamy partii «Narodna volia». 1882 r., 35 ark.

29. TsDIAUK, f.1335, op. 1, spr. 20. Tsyrkuliar departamentu politsii vid 3 kvitnia 1884 r. pro otrymannia vidomostej pro povodzhennia, obraz zhyttia i sudymosti neblahonadijnykh osib dukhovnoho zvannia $\mathrm{v}$ mistsevoho ieparkhial'noho nachal'stva. 222 ark.

30. TsDIAUK, f. 797, op. 48, vidd. 3, spr. 181. Po vidnoshenniu Holovnoho nachal'nyka 3 viddilennia Osobystoi Joho Velychnosti Kantseliarii pro prytiahnutykh do vidvidal'nosti u spravi zlochynnoi propahandy sviaschenykiv Kyivs'koi hub. Zvenyhorods'koho povitu sela Romejkovky Dmytra Mel'nykivs'koho i s. Kyrylivky Oleksiia Koshyka. 1878 r., ark. 1-8.

31. TsDiAUK, f. 442, op. 833, spr. 13. Perepyska z Volyn. hub. pro perevirku anonimnoi zaiavy pro nalezhnist' do taiemnoho tovarystva sviaschenyka s.Bubniv Volodymyrs'koho povitu Volyn. hub. Mal'chevskoho. 1883 r., ark. 1-3. 